\title{
Professor José Joaquim Cardozo de Mello Neto*.
}

\author{
José Pinto Antunes \\ Catedrático de Economia Política na Facul- \\ dade de Direito da Universidade de São Paulo.
}

Bem sei, meus senhores e minhas senhoras, que não sòmente as razões do coração mas, igualmente, as da inteligêneia não justificam nem explicam a dolorosa recordação que ora fazemos do passamento do Doutor José Joaquim Cardozo de Melo Neto, Professor emérito desta Casa e Mestre insígne de nós todos.

De fato, o coração se aperta outra vez em dor profunda que é a angústia de uma saudade sem remédio. $E$ justamente a mim, seu discipulo, seu amigo e companheiro de árduas lutas políticas, vai caber, pelos ditames universitários, o doloroso papel de reavivar, no trigésimo dia de sua morte, o sofrimento dos seus familiares e o desalento dos seus amigos.

A inteligência inconformada com a brutalidade do fato, explode a sua revolta contra o inexorável da Morte e a incompreensivel existência da Dor. Por que, perguntamos a nós mesmo, por que Aquêle, que tudo pode, não nos dá tôda a felicidade, não nos exime da dor, se a fé de cristão nos diz que é, Êle, Pai amantíssimo, isto é, o Pai de nossos pais, o Pai por excelência?! E ser pai é sofrer para que

* Discurso proferido em sessão solene realizada a 21 de agôsto do corrente ano no salão nobre desta Faculdade, em homenagem póstuma ao prof. Dr. José Joaquim Cardozo de Mello Neto. 


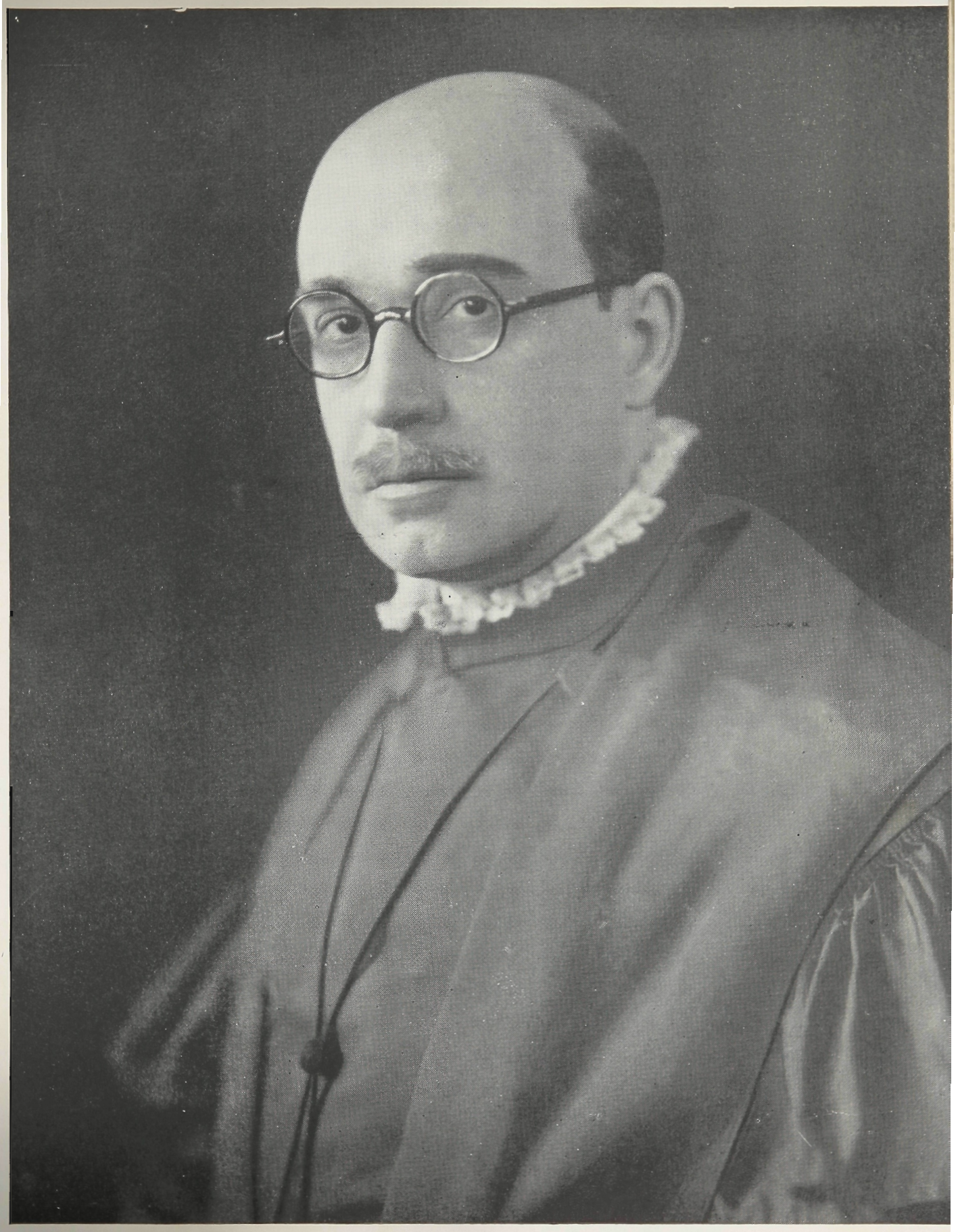


não sofram os filhos; é puro amor, é perdão sòmente e não castigo ou punição?! Por que nos deu a razão que não. explica a contraditória razão das coisas? A justificativa do pecado original, para a morte e o sofrimento, está em. contradição com o princípio da mesma razão, de que a pena não deve passar além do criminoso sem injustiça... Com qual razão ficamos? Qual é a que nos define como racionais?

Que razão contra as razões, esta, a de que nos dotaram, para a inquietude do nosso espírito, que não explica o infinito, nem a própria vida, que traz em si a constância da Dor e o inexorável da Morte?!

Mas, confundindo a anıbiciosa inteligência humana, responde Êle através dos séculos, lá do alto da montanha, em. sermão sagrado:

"Não vos inquieteis. Eu sou a verdade...

"...Quem veste os lírios do campo?..."

Deixemos, pois, a vã filosofia de uma razão impotente para compreender a grande Razão do Ser.

Curvados à Vontade do Senhor, vamos tornar a viver a nossa triste paixão com aquêles que nos ouvem, falando da vida, cheia de virtude e sabedoria, do Professor José Joaquim Cardozo de Melo Neto, a quem hoje, pela minha palavra, a Congregação da Faculdade de Direito do Largo de São Francisco presta as honras soleníssimas com que ela tem por timbre e por costume inscrever, nos fastos do seu patriciado, aquêles que muito a dignificaram pelo muito que fizeram pelos altos interêsses do Brasil.

José Joaquim Cardozo de Melo Neto dizem os assentamentos que nasceu na Capital do Estado de São Paulo em 19 de julho de 1883.

Mas, em nome da imperial cidade de Areias retifiquemos a história, com as suas próprias palavras, quando argumentava que a árvore se define pelo lugar em que planta: suas raizes e não por onde despeja os seus frutos. 
Cardozo de Melo Neto serviu a Capital de São Paulo como seu Prefeito, o Estado, como seu governador, e o Brasil, como constituinte e deputado federal, mas as raizes de sua nobre família estão entranhadas na terra daquela pequenina cidade paulista que mesmo depois de havida por uma das "cidades mortas" do Vale do Paraiba, reviveu e se eternizou na expressão do belo literário das obras de Monteiro Lobato e, hoje, é saudada pela seiva de civismo que alimentou brasileiros ilustres, como o homenageado e o seu ilustre pai, doutor José Joaquim Cardozo de Melo Júnior, o antigo e último Chefe de Polícia do Império. E de igual estirpe foi sua digníssima mãe D. Adalgisa Pinto Cardozo de Melo.

Casado com D. Celina, filha do Conselheiro Rodrigues Alves, era-lhe fácil a ascensão na carreira política através das fileiras do Partido Republicano Paulista.

Todavia, preferiu o seu patriotismo o caminho árduo da oposição, participando da fundação da Liga Nacionalista com o Professor Frederico Steidel e, assim, desencadeando, pela sua pregação cívica, os movimentos revolucionários que vêm acelerando o progresso social do Brasil. Pois não há exagêro em se dizer que daquele tronco cívico provieram o Partido Democrático e a Aliança Liberal, no campo civil, e a revolução de 1930 como movimento militar que destruíu a antiquada estrutura política do país, instituindo o voto secreto e outras medidas democráticas.

Quando o movimento democrático de 1930 degenerou em ditadura, foi o nosso Mestre um dos chefes da rebelião dos paulistas, em 1932 e, após a nossa derrota pelas armas, xetomou, voltou à luta pela palavra, através do Partido Democrático, cuja direção assumiu em substituição ao saudoso Professor Francisco Morato, exilado em Portugal.

Então, seduzidos pelas graças do Ditador, alguns se bondearam para o lado de lá, mas Cardozo de Melo Neto, tomado de ira santa, reune, de pronto, os seus companheiros de Diretório e redige manifesto dirigido à Nação, em 
nome da dignidade paulista, terminando com estas palavras candentes: "quanto a nós, do Partido Democrático, preferimos ficar com São Paulo, a cair súplices aos pés do vencedor".

Éste é o homem público que em 1930 foi Prefeito da Capital; depois, constituinte em 1934, líder da bancada do Partido Constitucionalista em 1936 e Governador do Estado de São Paulo em 1937.

Pertencia o Professor Cardozo de Melo Neto àquela estirpe de mestres que lecionava direito nas cátedras e pregava civismo nos comícios, preparando, pela palavra, pelo exemplo e pela ação, os jovens acadêmicos para os serviços da Pátria em transformação revolucionária.

Mestre de Economia Política, catedrático desde 2 de dezembro de 1920, lecionou Ciência das Finanças que, então, integrava aquela disciplina, além de Direito Administrativo, em substituição eventual do Professor Manuel Pedro Vilaboim.

Foi, também, um dos grandes Diretores desta Casa.

Sua doutrina econômica já não era o liberalismo do século 19, embora pregasse, ainda com timidez, a atividade intervencionista do Estado na ordem econômica, dizendo-se, porisso, filiado ao socialismo de cátedra.

Mais tarde avança nas suas lições e, quase profèticamente, delineia o intervencionismo liberal de Roosevelt ou intervencionismo de funcionamento de Keynes, dizendo-se filiado à escola intermédia, isto é, entre o socialismo e o antigo liberalismo. E, para explicação do seu pensamento, remetia-nos a um modesto economista brasileiro - Viera Souto, se não me falha a memória, onde o autor comparava o intervencionismo estatal ao modo da ação do jardineiro que afeiçoa o jardim com a sua tesoura, dando disciplina e harmonia aos desenvolvimentos naturais. .

Afinal, eram as potencialidades da iniciativa privada contidas nos seus excessos pelo direito. Era ainda o jurista temendo a fôrça explosiva do fator econômico e querendo 
canalizá-lo pela ação coordenadora da política geral. A Constituição de Weimar, de 1919, foi, talvez, a forma de transação e transição em que os liberais do século 19 se: transformaram em liberais do século 20. E o Professor Cardozo de Melo Neto pertence a êste grupo de economistas, ainda em dúvidas ante a necessidade da economia de duplo; setor, como solução ou promessa de solução para os problemas econômicos, postos, hoje, agressivamente, pelas massas sôfregas, famintas de igualdade econômica, e, por isso, sempre prontas para a violência em busca de nova ordem jurídica que condicione outra ordem econômica mais justa e humana do que aquela em que vivem e padecem.

Acreditava o nosso saudoso Professor no intervencionismo econômico sem revolução, realizando o desenvolvimento material sem desajuste ou distorções, a modo da extensão da gota de azeite que, harmônicamente, se espalha para os bordos da superfície a que se destina. $O$ direito, então, com o seu primado sôbre o econômico, é fôrça disciplinadora do lento e ordenado enriquecimento coletivo. Enfim, na linguagem dos nossos dias, pregava o desenvolvimento econòmico sem "queimar etapas".

Na luta entre o economista e o jurista, ficava com o jurista, acreditando nas suas fórmulas e no seu govêrno para multiplicação e difusão das riquezas.

Não seria, mais, agora, o homem do seu tempo. A sua constante satisfação, fácil e comunicativa, expressa-se, tambẻm, no seu otimismo doutrinário, fazendo dêle o último representante de uma geração de professôres tranqüilos e confiantes no ensino que transmitiam como conhecimentos: categóricos.

Até a sua expressão pitoresca com que paternalmente nos acolhia, o seu "muito ótimo" era a evidência daquela: tranqüilidade do mestre na direção doutrinária do discípulo.

Esta Faculdade pela responsabilidade, centenàriamente histórica, de fazer homens públicos, sente-se agora apreensiva e perplexa no seu ensino. 
O fator econômico, até então submisso à ordem jurídica, desprende-se do jugo legal e, de informado, passa a informante, porque dominador. As leis correm para vesti-lo e travá-lo com as suas fórmulas, mas êle continua avançando rebelde às disciplinas. Tranforma o Direito Privado em Direito Público. É o fato jurigeno de novas disciplinas jurídicas. Põe o Direito Constitucional em crise...

A economia dita e o direito obedece.

$\mathrm{E}$ tudo porque a igualdade formal de todos perante a lei, prometida pelo direito, não satisfaz mais às massas rebeladas que pedem garantia contra a fome e, pela participação nas riquezas econômicas, estão dispostas a pagar preço incomensurável dando, de barato, as conquistas democráticas do século 19. Daí o feliz êxito das ditaduras onde os demagogos acenam com a pronta extensão da riqueza a lodos, como se o desenvolvimento econômico e a riqueza coletiva fôssem programa de execução imediata e não dependente da produção e do tempo.

Temos que atentar, no nosso ensino, para o fato de que a universal insatisfação social pede medidas de emergência, mesmo contrárias às soluções melhores mas demoradas. As massas indóceis não se aquietam com a promessa de vida melhor para as futuras gerações, mas exigem, para já, a participação nas riquezas e no confôrto que o progresso técnico criou e que é, ainda, privilégio de "elites" econômicas.

É esta contradição criada pela extensão social dos desejos que abala a ordem jurídica e fá-la dependente da ordem econômica.

A crise do direito demanda solução ao economista e, êste, perplexo, não sabe como planejar o desenvolvimento econômico no ritmo da sofreguidão das massas necessitadas.

Promete a Constituição "vida digna a todos"; "flatus vocis", promessa jurídica vã, porque está fora da sua competência o aumento do dividendo social, condição para a lei de justa distribuiçâo das riquezas. 
Esta divagação, meus senhores e minhas senhoras, não é um pretexto do coração para fugir à dor do elogio fúnebre do grande Mestre desta Escola. Ao contrário, é o estudo da sua personalidade "sub specie aeternitatis".

Cardozo de Melo Neto é a afirmação da liberdade como principio ordenador na ordem econômica e jurídica. $E$ nós, que o substituimos na cátedra, aceitamos o princípio no campo do ideal, mas não sabemos como serví-lo adequadamente ou aplicá-lo nas contingências de uma sociedade em revolta pela carência dos bens que lhe são vitais. Com êle, condenamos o Estado como mau produtor, mas não vemos como aumentar a produção e efetivar as mutações técnicas sem os grandes capitais que somente a riqueza ou o crédito do Estado podem realizar.

Cardozo de Melo Neto ensinava as linhas do ideal econômico-jurídico da convivência com justiça. Nós, oprimidos pelas exigências do cotidiano, transigimos com o ideal e tememos, assim, pelo resultado das mesinhas de emergência.

Deixou o Mestre, cuja memória reverenciamos, o otimismo do sábio que vive na tranqüilidade da ciência. Mas, ao mesmo tempo, pela sua ação política, responde por esta revolução dos fatos sociais, criando, assim, para os seus discípulos e sucessores, graves problemas de uma sociedade que desperta pedindo, com urgência, a formulação de uma nova ordem econômica e a conseqüente reformulação da ordem jurídica vigente.

Não sei, não. Mas, para nós, é mais uma lição do Mestre que, lá do alto dos céus, nos está distribuindo a tarefa ingente de preparar a mocidade de sua querida Academia para a construção de um novo Brasil, onde continui a sobreviver a liberdade mas que sobreviva sem as aflições de sua sofrida população.

Meus senhores e minhas senhoras.

Já se falou demais para o sofrimento de uma saudade. 
Pensemos, antes, que o Professor Cardozo de Melo Neto está alí na Congregação com o seu sorriso de gentil-homem mas com a sua feição diretora. Elegante, austero, afável e disciplinador.

Pensemos que já conseguiu a eternidade da lembrança com o nome esculpido nas pedras centenárias das Arcadas.

Recordemos, ainda, que êle abriu páginas brilhantes da história de São Paulo e do Brasil com a coragem do seu civismo e a sábia inteligência de Mestre e de Político.

Vive êle em Cristo por tôda a eternidade e nos corações, pelas virtualidades do amor dos seus amigos e dos seus desolados discípulos. 